\title{
Application of Information Processing Strategies to Discourse Listening
}

\author{
Some Cognitive Approaches
}

\author{
Chunqi Li \\ Hebei Vocational College of Foreign Languages \\ Qinhuangdao, China
}

\begin{abstract}
This paper presents arguments for the relationship between information processing strategy application and listening comprehension achievements from a cognitive perspective. An experiment is carried out to discover learners' main information processing difficulties at three mental stages when listening to discourses and test the impact of effective strategy application on the listening achievements of three different levels of language learners.
\end{abstract}

Keywords-information processing strategies; strategy application; listening comprehension

\section{INTRODUCTION}

It is widely accepted that listening is vital in the language classroom because it provides all the input for the learners. As listening comprehension is an active and complex activity, it requires a lot of mental activities of inputting, encoding, decoding, memorizing, retrieving and outputting of information on the part of the learners. Learners can hopefully improve their listening comprehension competence with the practice of cognitive skills.

The activity of listening to one or more stretches of words with a referential context is known as discourse listening. When listening to discourses, it usually begins with one's attention to sounds or speech patterns, and proceeds through identification and recognition of specific auditory signals, ending in comprehension. Linguists gave different names for such processes. Cook (1992) named them access to vocabulary, parsing, and memory processes; Gui (1991) defined them as perception, construction and utilization processes; The widely accepted classification was put forward by Anderson(1983) as perception, parsing and utilization. Whatever these processes are named, they basically go through three mental structures of Information Processing System (IPS) in psychological terms: sensory store, short-term memory (working memory) and long-term memory. Based on the previous studies, we are attempting to figure out when and how the commonly mentioned difficulties arise in the process of listening and whether there are other difficulties blocking listeners' way to comprehension. Will training of strategy applications improve all levels of listeners uniformly?

\section{LITERATURE REVIEW}

Extensive researches have been done on the exploration of listening problems and listening strategies. The most influential ones include the studies of Murphy $(1985,1987), \mathrm{O}^{\prime}$ Malley and Chamot (1990), Rost and Ross (1991), Rubin (1994), Field (1998), Goh (2000, 2002), Nunan (2002), Wilson (2003), Field (2010) etc. on the understanding of listening difficulties and application of strategies for distinctive levels of listeners in enhancing listening comprehension competence.

Murphy $(1985,1987)$ concluded some common sequential patterns of strategies that listeners at different proficiency levels follow. In Rost and Ross (1991), a correlated study between certain strategy use and language proficiency was carried out. It made a conclusion after a training experiment that listeners at elementary, intermediate and advanced levels showed improvement in listening comprehension and were able to predict questions and infer answers. Wilson (2003) reemphasized the importance of bottom-up approach in listening comprehension class in spite of the wide acceptance of top-down approach. Field argued that some individual sub-skills such as inferencing are more crucial than understanding itself and recently put forward two alternatives to the "practice makes perfect" listening teaching approach. He proposed the use of a communicative methodology and a focus on the process of listening to improve the current listening practice (Field 1998, 2010).

\section{Methodology}

\section{A. Pre-research Questions}

This experiment is about to answer two questions as a further development of Rost and Ross (1991) and Field (2010) concerning strategies and listening comprehension. Are the listening habits and application approaches of IP strategies correlated with achievements of listening comprehension? And will the cognitive approaches to application of IP strategies effectively improve the listening achievements of high, intermediate and low achievers in terms of listening comprehension to the same degree?

\section{B. Subjects}

The subjects were fifty-eight Chinese students chosen from College of Information science and Engineering of Northeastern University, who were freshmen in their second semester. The criteria for sampling is that the target group of 
learners must have learned English for over six years and importantly, they must be willing to cooperate in this study. We take the participants' latest scores of CET4 test as reference to assess the reliability of the experimental test in this study. We divide the participants into three groups in terms of listening achievement, they are, H(high achievers)group, IT(Intermediate achievers) group and L(Low achievers) group.

\section{Instruments}

In this study, four types of instruments were adopted. They are questionnaire, interview, training program and listening test. Each of the students will be asked to fill a questionnaire on their individual listening background and problems. Referring to feedback of the questionnaires, interviews are held with students selected from each group. After the survey, a strategy application training program is held to instruct skills as to how to apply strategies effectively to listening comprehension.

\section{Data Collection and Analysis}

Questionnaires are handed out to the subjects to get individual information about listening comprehension. And interviews are held with three representatives from each level group after the analysis of questionnaires. The questionnaire is consisted of 10 questions which are concerned with listening views, habits and attention problems.

After collecting the data of questionnaires, we make a correlation analysis between CET4 mean score and views on listening, listening habits, attention problems via statistical software SPSS and the result shows that it is significantly correlated between listening achievements and views, habits as well as attention problem. However, among the comparisons, the co-efficiencies between mean scores and habits are most significant at $0.890,0.634,0.573$, for three groups respectively. And attention factor is secondary to habits in correlation to mean score at $0.569,0.631,0412$. The rank of correlation from highest to lowest is IT group, $\mathrm{H}$ group and L group. This result explains that good habits are very influential for listening achievement. Frequent practice and effective approaches are helpful in enhancing a student's listening comprehension. On the contrary, lack of good listening habit affects listening comprehension on the negative side, but not as explicit in this analysis. Although all the participants have attention problems, the intermediate group members are the most obvious. They believe that the improvement of attention will help enhance the effects of listening comprehension.

Interviews with representatives selected from each group were held, talking about the specific difficulties they have in the process of listening. They were asked to report orally while they were doing listening comprehension tasks. This is also known as "think-aloud" method, and questions asked in the interview section are partly referred to those listed in Goh (2000, p59). According to the data of recordings, we summarized the most frequently arisen difficulties for each group in terms of three phases of information processing:

H group: Confused about the key ideas or intended meaning of the message. (Utilization)
IT group: Neglect the next part when thinking about meaning. (Perception)

Unable to form a mental representation from words heard. (Parsing)

L group: Unable to associate sounds with familiar words. (Perception)

\section{Quickly forget what is heard. (Parsing)}

It is seen from the above that the primary difficulty for High achievers group mainly appears in the utilization phase, in which learners' ability of decoding and interpreting is required. But primary difficulties for Intermediate and Low achievers group center mainly on the perceptual and parsing phases, involving sensing, encoding and memorizing skills. However, the above problems are not all those that learners meet in the process of listening. There are some other ones, such as unable to follow the speed, unable to form a text with words heard etc., though not as tough for many as the above mentioned.

\section{E. Listening Training Program}

In view of the above analysis, a training program of listening strategy application is planned and carried out. This program which lasts for only one month with 6 periods of class per week is not about to improve the learner's listening comprehension competence fundamentally, but to suggest effective ways to apply 7 most commonly suggested strategies (Contextual inference, Backgrounding/Image schemata, Word guessing, Gist listening, Pre-inquiry/presumption, Note-taking, Repeating) into listening comprehension. The four ways suggested in the training program are interactive, selective, industrious and contextualized application. Students were asked to spend half time learning and taking in these key skills, and half time practicing how to realize them in the listening comprehension processes.

\section{1) Illustration of Strategy-application}

The application of strategies can facilitate listening comprehension if employed appropriately and retard if not. It is highly suggested to use interactive, selective, industrious and contextualized approaches of application, in an individualized way.

According to the interactive application approach, an integrated use of strategies can increase the effect of listening comprehension to a larger extent. For instance, the application of Contextual inference often combines with Backgrounding, Word guessing and Gist listening. But learners at different levels combine them in dissimilar ways. The most effective use of these strategies is to find the clues of grammatical and lexical cohesion. (Halliday \& Hasan, 1976) The devices of grammatical cohesion include reference, substitution, ellipsis, and conjunction, some of which must make use of a few lexical markers such as "this/that" "moreover" "however" etc. to realize their functions. Such grammatical markers or logical connectors often take the role of providing the cohesive ties of meaning which could pull the text together. Thus, the interaction between vocabulary knowledge, grammatical knowledge and background knowledge will activate listening comprehension. 
Selective application of strategies is significant for ineffective listeners and those who are confused with some sounds or words in a sentence or passage. This approach suggests that learners give up some of the former listening habits and take up only one or two strategies such as listening to main ideas instead of listening to words, Pre-inquiring instead of waiting for questions or messages. To finish different listening tasks needs different selection of strategies. When doing listening comprehension in the form of multi-choice questions, true or false questions or summary writing, don't try to grasp both the main ideas and meaning of every word, for things that stay in the sensory store are transient and the span of short-term memory is very limited in recalling all of the information without any written cues. Try to grasp the gist of the passage or conversation, and infer the underlying information from the context.

The industrious application of strategies is a good way to deal with the problem of inattention for ineffective listeners. By "industrious", it means to use hand together with brain and ear in a proper way. This approach is especially suitable for those whose attentions are easily distracted by other auditory stimuli. By the aid of note-taking and silent repetition in a long conversation or passage listening can help learners solve the problems of lack of attention and limited span of short-term memory. But when applying this approach, one must consider the question types whether they are comprehensive listening or dictational listening, and whether the speed and length of the listening material are appropriate for you to take notes.

Contextualized application of strategies requires learners to have a contextual view in the process of comprehending. No matter you interactively, selectively or industriously apply the strategies, you must choose the most relevant ones in terms of the context of the listening. When you choose an individual strategy, for instance, Backgrounding/Image schemata, or Word guessing, you should recall knowledge or information related to context. And as Edwards (2009) pointed out that students will see how a new item works grammatically and the context will help make the item more memorable and aid retention. Also, according to speech act theory, in order for a conversation to proceed smoothly, participants must assume that all participants will adhere to certain conversational maxim or cooperative principle which can be said to constrain the speaker's action in such a way that the hearer will be more likely to discover underlying intentions.

\section{2) Post-testing Analysis}

After the training program, all the participants are asked to accomplish a 35minutes' listening test which is made consistent with an authentic CET4 listening test in number, form and degree of difficulty. It is composed of three sections: multiple choices questions for short and long conversations; multiple choices questions for short passages; and compound dictation for a long passage. At the beginning of the test, teacher reminds the students to try their best to focus and apply strategies. After the experimental test, we make a comparison with CET 4 scores for each group to see whether there exists some significant difference after the training program.
TABLE 1. THE SCORES OF EACH GROUP BEFORE AND AFTER TRAINING

\begin{tabular}{lcccc}
\hline & Numbers & Mean score & t & $\begin{array}{c}\text { Sig. } \\
\text { (2-tailed) }\end{array}$ \\
H group & 16 & 85 & & \\
& 16 & 87 & 4.373 & 0.028 \\
IT group & 25 & 72 & & \\
& 25 & 81 & 3.121 & $0.000^{*}$ \\
L group & 17 & 61 & & \\
& 17 & 67 & 4.011 & 0.001 \\
\hline
\end{tabular}

An independent t-test is run to compare each experimental group's pre-testing (CET 4) mean score and post-testing mean score in order to figure out the effect of listening strategy training on the improvement of listening comprehension achievement for each level of group.

The t-observed values for three groups are 4.373, 3.121, 4.011 (Table 1). Each of the t-values is higher than the critical value of 2.004 at 55 degrees of freedom. Based on these results, it can be concluded that there is a significant difference $(\mathrm{p}<.05)$ between pretest and posttest's mean scores for each of the experimental groups. However, IT group has the most obvious significant difference at .000 and L group followed at .001. The mean scores of $\mathrm{H}$ group are not significantly different before and after the training program.

\section{FINDINGS}

In conclusion, this experimental study provides evidence to answer two pre-questions that IP strategies can have a positive impact on the listening achievement if applied appropriately. In addition, intermediate and low achievers of listening comprehension can gain more benefits from the strategy application training than the high achievers.

Discourse listening comprehension is a rather complicated process during which a learner's information processing system plays a decisive role. A Learner must take the optimal management of limited available resources to have a better understanding of the oral text. This study provides a further examination in detail of how a successful listening comprehension can happen with effective applications of information processing strategies in the course of discourse listening.

An effective application of listening strategies can facilitate students to capitalize on the input of fragmental information, and to achieve a greater success in listening comprehension. Findings of this experiment help to confirm the close relationship between listening habits, strategy application and listening comprehension results, and reveal that the intermediate and low achievers can benefit more after the explicit instruction of listening strategy application skills. With the result of this study, we conclude that the selection of effective approaches to applying Information Processing strategies to discourse listening is very essential for language learners and that an explicit cognitive strategy teaching of listening comprehension is very instructive in EFL listening class. 


\section{REFERENCES}

[1] Anderson, J. R. (1983). A spreading activation theory of memory. Journal of verbal learning and verbal behavior, 22.3 : 261-295. http:// dx. doi:10.1016/s0022-5371(83)90201-3.

[2] Cook, V. (1992). Second Language Learning and Language Teaching. Edward Arnold.

[3] Edwards, L. (2009). How to teach Vocabulary. Pearson Education. Retrieved May 30, 2013, from http://pearsonlongman.com. htm.

[4] Field, John. (1998). Skills and strategies: Towards a new methodology for listening. ELT Journal, 52.2 : 110-118. http:// dx.doi.org/ 10.1093/elt/ccq026

[5] Field, J. (2010). Listening in the language classroom. ELT Journal, 64.3: 331-333. http:// dx.doi: 10.1093/elt/ccp090.

[6] Goh, C. C. M. (2000). A cognitive perspective on language learners' listening comprehension problems. System, 28, 55-75. http://dx.doi.org/10.1016/S0346-251X(99)00060-3.

[7] Goh, C. C. M. (2002). Exploring listening comprehension tactics and their interaction patterns. System, 30, 185-206. http://dx.doi.org/10.1016/S0346-251X(02)00004-0

[8] Gui, S. C. (1991). Essentials of Experimental Psycholinguistics. Hunan Education Press.

[9] Halliday, M.A.K., \& Hasan, R. (1976). Cohesion in English. London: Longman

[10] Murphy, J. M. (1985). An investigation into the listening strategies of ESL college students. ERIC Document Reproduction Service No. ED 278275.

[11] Murphy, J. M. (1987). The listening strategies of English as a second language college students. Research \& Teaching in Developmental Education, 4 (1), 27-46.

[12] Nunan, D. (2002). Listening in language learning. Methodology in language teaching: An anthology of current practice, 238-241.

[13] O’Malley, J., \& Chamot, A.U. (1990). Learning Strategies in Second Language Acquisition, Cambridge University Press.

[14] Rost, M., \& Ross. S (1991). Learner Use of Strategies in Interaction: Typology and Teachability. Language Learning, 41( 2), 235-273. http:// dx.doi.org/ 10.1111/j.1467-1770.1991.tb00685.x

[15] Rubin, J. (1994). A review of second language listening comprehension research. Modern Language Journal, 78, 199-221. http:// dx.doi.org/10.1111/j.1540-4781.1994.tb02034.x

[16] Skehan, P. (1989). Individual Differences in Second Language Learning. London: Edward Arnold.

[17] Wilson, M. (2003). Discovery Listening Improving Perceptual Processing. $\quad$ ELT Journal, 57.4: 335-343. http:// dx.doi.org/ 10.1093/elt/57.4.335 